\title{
The Folklore Archive of the University of the Balearic Islands
}

\author{
Jaume Guiscafrè Danús \\ University of the Balearic Islands \\ jaume.guiscafre@uib.cat
}

\begin{abstract}
The Folklore Archive of the University of the Balearic Islands is a modest but ambitious project that is currently in the initial stage of being set up. It is part of the Historical Archive, of which it is one collection, although the Department of Catalan Philology and General Linguistics is responsible for its academic supervision. At this stage, it mainly comprises a subcollection of course work produced by students on folklore and popular oral literature. This article sets out the theoretical and methodological bases, the background to the project and the purposes for which it was set up. It also discusses the tools for managing the archive, and the collection, subcollections, series and subseries of which it is made up.
\end{abstract}

KEYWORDS

Folklore; popular oral literature; folkloristics; fieldwork; archives

RESUM

L'Arxiu de Folklore de la Universitat de les Illes Balears és un projecte modest, però ambiciós, que es troba en la seva fase inicial de construcció. Està integrat en l'organigrama de l'Arxiu Històric, del qual constitueix un dels fons, però la seva supervisió acadèmica va a càrrec del Departament de Filologia Catalana i Lingüística General. Està constituït, inicialment, per un subfons integrat per treballs de curs que han elaborat alumnes de la mateixa universitat com a activitat d'avaluació d'assignatures relacionades amb el folklore i la literatura oral popular. En aquest article s'expliquen els fonaments teòrics i metodològics en què es basa, els antecedents que n'han fet possible la constitució i els propòsits amb què es va crear. Així mateix, se'n descriuen les eines de gestió $i$ el fons, el subfons, les sèries i les subsèries que l'integren.

PARAULES CLAU

Folklore; literatura oral popular; folklorística; treball de camp; arxius

REBUT: 03/IO/2OI6 | ACCEPTAT: I9/IO/2OI6

Estudis de Literatura Oral Popular, núm. 5, 20I6, I9-28 | DOI: Io.I7345/elop20I6I9-28

ISSN: 20I4-7996 | http://revistes.urv.cat/index.php/elop 


\section{Folklore archiving ${ }^{1}$}

In the past, I have highlighted (Guiscafrè 20I4: 44) the usefulness of Roviró's concept of "arxivística folklòrica" [folklore archiving] (I992: 77) to designate the "vell estudi del folklore" [old study of folklore] that is interested "més pel contingut i pel resultat que per la forma d'assoliment i d'aparició del text folkloric" [more in the content and result than in how folkloric texts were attained and appeared] and where "no importava ni l'ús, ni el mitjà ni la finalitat, sinó el resultat fossilitzat, descontextualitzat" [neither the use, medium nor purpose mattered, only the fossilised, decontextualised result]. On the one hand, the practice described by Roviró, which is not in fact so old since there is a legion of educated laymen who still work in this way, is designed exclusively to obtain texts and materials. This can be explained by various circumstances: for example, the precarious nature of the technical resources available to folklorists in the $19^{\text {th }}$ century and much of the $2 \mathrm{O}^{\text {th }}$, the almost complete lack of theoretical training and fieldwork based on a selective concept of folklore, the acquisition of information through interviews or the canonisation of the ideal informant. On the other, folklore archival science ignores essential aspects that are inherent to any communicative interaction (oral, written or iconographic) between individuals in direct contact: the implied agents, the purpose with which the sender updates or proposes the text, the perlocutionary effect it has on the receiver, the specific social context in which the sender and receiver interact, etc. In the best-case scenario, the result of fieldwork in these conditions is a text, recording and/or transcript that has limited usefulness for scholars, although it is not entirely useless. Although it is true, as Dundes states about jokes, that "contextless jokes are of limited value to the social scientist", it is no less true that "variants of jokes, recorded without context, may be of value to historic-geographers plotting paths of diffusion, determining degrees of cognation, and postulating development sequences of subtypes" (I980: 26). This is just as true for jokes as for legends, proverbs, songs, drawing or memes.

The study of folklore inevitably leads to archival practice as, otherwise, the alternative is disregard, oblivion and, finally, disappearance. And this dynamic affects not only genres at risk of extinction or which are no longer current, such as tales of magic, historical legends or work songs, but also contemporary oral and non-oral folklore: the topical joke about Spanish PM Mariano Rajoy told by a mocking son-in-law after Christmas lunch to annoy his father-in-law fades away with the laughter of those present; university cleaning staff are becoming increasingly effective and latrinalia is now more valuable than before given its scarcity; municipal street cleaners have declared war on graffiti, especially that which calls the town council into question, and every day, a huge amount of electronic folklore is disappearing as people's smartphone sim cards need space to load and manage apps, photos and videos which, in turn, are used to create more electronic folklore. Without archiving, a corpus cannot be established so that researchers can study traditions, circulation methods and ecotypification

I. This article is a product of a line of research on Catalan folk literature funded by the Spanish Ministry of Economy and Competitiviness through the research and developement project FFI2OI5-64I28-P (MINECO/FEDER). 
processes, and to carry out comparative studies or establish general theoretical principles.

This is why I propose widening the meaning of the term "folklore archiving" so that it can also be applied to creating, conserving and managing archives which folklorists inevitably have to deal with. This "new folklore archiving", if you will, must be based on the idea that an archive is much more than a simple warehouse and must be based on a conception of folklore that does not focus exclusively on texts. This archival practice should also comply with minimum standards in each of the three research stages (collection, archiving and analysis of material), undertake initiatives that contribute to the circulation of materials and, finally, have a general dynamic that stimulates folklore learning and promotes research into archived material. ${ }^{2}$

\section{Teaching folklore and popular oral literature at the University of the Balearic Islands}

The first syllabus for the Degree in Catalan Philology at the University of the Balearic Islands was approved in I983, just five years after the university was founded. This degree programme was regarded as an important one because of its direct links to the culture and language of the Balearic Islands. The programme was taught for the first time in the academic year I983-I984 and since then, the course has been offered every single year.

Subjects related to folklore and popular oral literature have also been continuously offered as part of the successive undergraduate and postgraduate degree syllabuses available on the programmes at the Department of Catalan Philology and General Linguistics.

The syllabus of the I983 Degree in Catalan Philology included the elective subject of Popular Catalan Literature; the I984 syllabus also contained this subject, although now as an obligatory course. The I997 syllabus maintained the course as an obligatory subject whilst adding an elective in Oral Literature. The Catalan Language and Literature syllabus in the academic year 2009-2010 included the obligatory subjects of Folklore Theory and Catalan Ethnopoetics.

With regard to postgraduate studies, the syllabus for the Master's Degree in Catalan Language and Literature: Orality and Writing, which was offered between 2009 and 20I4, contained the elective subjects Narrative Folklore and Popular Catalan Poetry. The current syllabus for the Master's Degree in Catalan Language and Literature: Knowledge and Critical Analysis of Intangible Heritage, in force since 20I4, includes the obligatory subject of Oral and Popular Catalan Literature in one of the teaching modules and the elective subject Popular Myths in $2 \mathrm{O}^{\text {th }}$-Century Catalan Literature.

Teaching for all these subjects has, in general, had a historical and literary focus, meaning that it has almost exclusively looked at oral or oral tradition poetry and narrative folklore compiled and edited by the top island folklorists in the $19^{\text {th }}$ and $2 \mathrm{O}^{\text {th }}$ centuries (Guiscafrè 20I4: 40). By adapting the courses to the European Higher Education Area and the subsequent approval of the degree syllabus, teaching was refocused for the two subjects. In essence, this refocusing

2. For more on folklore archives, see for instance Toelken (I996: 360-380). 
meant that teaching programmes complemented one another, in an attempt to cover all genres and all forms of folklore communication and popular oral literature, without falling into the trap of prestigious or obsolete genres, and that content was to some extent specialised. The Theory of Folklore, which I teach, aims to introduce students to the study of folklore, understood as a creative and interactive social process, and folkloristics, understood as the discipline that compiles, analyses, archives, edits and studies folklore. In turn, Catalan Ethnopoetics, taught by Caterina Valriu, intends to introduce students to the study and analysis of oral literature, understood as an aesthetic configuration of human communication in constant evolution and, therefore, a study of the main features of folkloric prose and verse genres with a special focus on output in Catalan.

Within the framework of all these subjects, the various lecturers have almost systematically asked students to do coursework that can be assessed to determine the extent to which they have acquired specific skills and knowledge. The nature of the coursework has been varied (life stories, bibliographic summaries, comparative analyses of published texts, transcription and edition of unpublished manuscripts, monographic studies, etc.) albeit with a predilection for fieldwork comprising the collection, transcription and critical commentary of a set of folkloric or oral literary texts. The theoretical premises and purposes with which each lecturer planned this activity were diverse and not all genres were considered equally. For example, when Gabriel Janer taught Popular Catalan Literature he focused on oral and oral tradition poets from the Balearic Islands and their poetic works. In contrast, in the first two years that I taught the subject in Oral Literature, I steered work exclusively towards contemporary jokes. From the 2004-2005 academic year, however, I chose to follow the research work model proposed by Oriol (2002: I29-I42).

\section{The Folklore Archive of the University of the Balearic Islands}

\subsection{Creation and objectives}

Based on the premises and reflections set out in section I herein, and following the inspiring example of the Folklore Archive at the Department of Catalan Studies at the Rovira i Virgili University, the Folklore Archive of the University of the Balearic Islands was set up in 2013 with the initial idea of collecting, sorting and classifying the coursework both Caterina Valriu and I had saved in a more or less ordered fashion in our offices. This contained a significant amount of folklore and other material from popular oral literature from Majorca and the other Balearic islands, as well as occasional examples from other Catalan-speaking countries: photocopies, transcriptions and published texts, audio and video recordings, photographs and computer files.

As well as this initial purpose, however, the Folklore Archive was set up with three main objectives to be fulfilled as per available budget and staff, which for the time being are rather scarce.

The first objective is to sort, classify and conserve the collection's resources. This has been, and remains, the priority we have dedicated our efforts to in the last three years. We have received invaluable support from four collaborating 
students (Joan Carles Munar, Laura Sastre, Natalia Hendriks and Joan González) and advice and personal commitment from Miquel Pastor, head of the Library and Documentation Service at the University of the Balearic Islands. ${ }^{3}$ Thanks to their commitment, the initial sorting, classification and bibliographic description tasks for the material in the Archive is at an advanced stage and we foresee ourselves soon being in the position to be able to publish the information.

The second objective is to create a bibliographic and specialised collection of folklore and popular oral literature resources. The academic activity in both teaching and research linked to the subjects mentioned above has led to specialised bibliographic resources being acquired on the subjects that have been studied. Thus, the aim is to bring together these bibliographic resources and make them available to students and researchers who may be interested, and to staff who may be involved in the cataloguing and description of the Archive's material.

The third objective is to promote research into folklore and popular oral literature, as well as its dissemination, in collaboration with the Department of Catalan Philology and General Linguistics, and other institutions. This aim comes from the belief that the activity of the Folklore Archive should not just be limited to folklore archival science but go beyond the strict university setting. In this vein, contacts have been made with other non-university institutions throughout 2016 with a view to future collaboration. The Island Heritage Department at the Island Council of Majorca has brought together different institutions and agents, including the Folklore Archive, which undertake tasks and projects linked to archive management, folklore and popular oral literature or intangible heritage, with the main aim of establishing a coordinated, planned and crosscutting programme of activities. The first step in the design of this programme involves drafting a document on the current situation of the material held by the various archives and the resources available to manage them. Unfortunately, the medium- to long-term viability of these projects is often seriously compromised every time there are elections and different parties come to power in the Government of the Balearic Islands. The reason for this is that, depending on the ideological beliefs of the politicians, activities regarding popular culture and intangible heritage habitually veer between promoting conservative regionalist folklore with an identity-centred nature and a sincere interest in promoting the collection, study, conservation, protection and circulation of an entire set of cultural manifestations from the island.

\subsection{Organic affiliation and resource management}

Although the academic supervision of the Folklore Archive is ensured by the Department of Catalan Philology and General Linguistics, the collection is part

3. Although we do not have any research assistants, these collaborating students have ensured that tasks, which would otherwise have gone undone, have been carried out. The call for collaborating student places is done every year. Applicants for the Folklore Archive must be fourth-year undergraduate students who are enrolled on the Theory of Folklore subject or, preferentially, have already taken the subject. Collaboration means students must dedicate one hundred and fifty hours (equivalent to six academic credits) to the tasks assigned to them by their tutor. 
of the Historical Archive of the University of the Balearic Islands. This Archive was created in I988. Executive Agreement 937 of $15^{\text {th }}$ January I990 allocated space in the Ramon Llull Building to "physically house the material and documentation relating to the Historical Archive of the University". ${ }^{4}$ Since I99I, documentation and material from public and private archives have been added, especially from donations and individual purchases. Both the Historical Archive and the Folklore Archive are currently housed on the first floor of the Ramon Llull Building at the university campus.

The affiliation of the Folklore Archive to the Historical Archive has enabled us, from the beginning, to benefit from the knowledge and experience in bibliographic management and archive description of the staff working there. In turn, to manage the collection we use the same bibliographic description and management program the staff at the Library and Documentation Service work with (ICA-AtoM), a "web-based archival description software that is based on International Council on Archives ("ICA") standards". It is a multilingual, open-source software program that "supports multi-repository collections" and which was initially developed by "Artefactual Systems in collaboration with the ICA Program Commission (PCOM) and a growing network of international partners". ${ }^{5}$ ICA-AtoM (International Council on Archives-Access to Memory) is an international project that provides institutions with a tool to disseminate their archival collections over the internet.

\subsection{Description of the subcollection and document series}

At this time, the Folklore Archive collection comprises a single subcollection of work done by students on one or several undergraduate or postgraduate degree subjects on folklore and popular oral literature, as well as final degree projects or master's theses.

This subcollection currently has four series: Subject Coursework, Final Degree Projects, Final Master's Projects and Theses. The Subject Coursework series is at the most advanced stage of collection and description, and is split into five subseries: Oral Literature (LO2085), which includes work submitted between 2003 and 2009; Popular Catalan Literature (LPCo899), which includes work submitted between 2007 and 20IO; Folklore Theory (TF207I6) and Catalan Ethnopoetics (EP2O72O), which contains work submitted from 2OII onwards; and Narrative Folklore (FNIO37I), which includes work submitted from 2013 onwards. Each of these five subseries is of different sizes: the most extensive is currently Oral Literature (sixty-three studies) whilst Narrative Folklore contains only six.

Each item is described with three blocks of information. The identification area includes the item reference code, the title (the coursework title and also the author's name and surname), the date or dates the study was created, the corresponding description level and information regarding length (number of pages), the medium it is saved on (paper and/or digital format) and the accompanying appendices (audio or video). The context area provides information on who produced the item and the archival institution where it

4. <https://seu.uib.cat/fou/acord/o9/937.html> [consulted: 23/o9/20I6].

5. <https://www.ica-atom.org/> [consulted: 23/o9/20I6]. 
is held. All coursework items state the name and surname of two creators: the student, as the author, and the supervising subject lecturer who commissioned and assessed the work. The lecturer information also contains a short biography with details about his/her teaching and research activities. The information on the archival institution provides a link to the Historical Archive of the University of the Balearic Islands for general and service information. Finally, the access points block contains information on the three possible access points for the information on each item: subject (stating the area of interest of each item and, for our purposes, the folklore genre(s) looked at in each one); location (information on the town(s) where the material was collected or where the interviewees are from), and finally, authority (again providing information about who produced the study and details about the interviewees). The information contained in the context and access points areas is presented as a link to enable users to access all instances where the producer, subject, location and authority occur in the general database of the Historical Archive (see figure I).

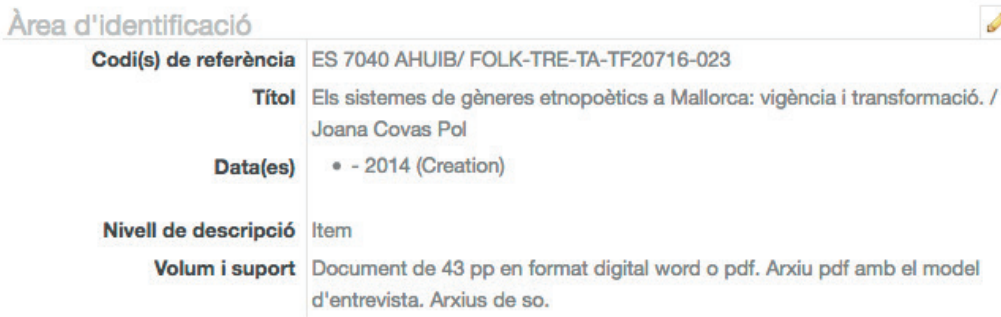

Figure I 
The number of subcollections, series and subseries can be extended according to the needs of the Archive. This option further confirms our desire to add work from other subjects or from the aforementioned subjects taught on academic courses that are currently not included, as well as original or digital copies of material from other individual archives which are currently difficult for researchers to access. This is true, for example, of Gabriel Janer's personal archive or the material intended for the failed Folklore and Bibliography Archive of the Balearic Islands (a highly ambitious project promoted by the folklorist Andreu Ferrer, I887-I975, which was never to see the light of day), which is currently split amongst several individual archives.

The Folklore Archive currently contains over three hundred pieces of student coursework, two hundred and thirty-five of which already have an archival description. The number of samples of folklore and popular oral literature surpasses three thousand and there are examples of both renowned, prestigious genres that have received preferential attention from scholars, and more marginal and less studied examples. The ICA-AtoM "allows the user to link a single digital object and import multiple digital objects, such as scanned images, sound and moving image files, and other scanned or born-digital items", ${ }^{6}$ on the condition that each digital item must be linked to an archival description, normally at subseries or item level. In the future, this option will enable online selection of work content or entire works with the accompanying audio and/or image files.

A further fundamental premise of the Archive is the belief that highly diverse and often overlooked contemporary folklore should become a part of the archive so that it can become a corpus for description, analysis and study. I started a collection of electronic folklore at the start of $200 \mathrm{I}$ that is set to become another subcollection in the Archive. It comprises material from e-mails sent to me by colleagues, students, friends and family, and other more recent material from interaction on Facebook, Twitter and WhatsApp. ${ }^{7}$ It contains examples of almost all non-oral folklore forms documented by Dundes and Pagter (I975, I987, I99I, I995 and I999) or listed by Brunvand (200I: 64-65): jokes, cyberproverbs, anecdotes, parodies, slogans, rumours, forms, questionnaires, pranks, false alarms, hoaxes, false virus alerts, chain letters, games, poems, conspiracy theories, recipes, funny drawings, one-liners, greetings cards, double-entendres, definitions, etc.

In the clear desire to strengthen and consolidate the links between the Folklore Archive and the Degree in Catalan Language and Literature, as from the academic year 20I4-2OI5 coursework by students on the Folklore Theory course is conceived and designed to become part of the Archive's collection. This comprises fieldwork in which all students must interview four to six people from a specific age range. The scripted interview must be recorded and involve the genres known and/or used commonly by interviewees, without overlooking contextual aspects. As part of the work production process, students must fill in and sign the material rights transfer form that sets out the terms in which their

\footnotetext{
6. <https://wiki.ica-atom.org/Upload_digital_objects> [consulted: 23/o9/20I6].

7. This practice of sending folkloric texts via e-mail has clearly been on the wane thanks to the more interactive, dynamic and immediate circulation on social networks and current smartphones.
} 
work will become part of the Folklore Archive. In turn, each interviewee must fill in and sign the interview permission form that sets out the query and use limits that will apply to the work once it is deposited.

\section{Evaluation and Perspectives}

It would seem that now, three years after creating the Folklore Archive of the University of the Balearic Islands, we can say that the founding objectives are in the process of being fulfilled.

On the one hand, having a collaborating student for each academic year and the support of the head of the Library and Documentation Service and staff at the Historical Archive enables us to make progress in classifying, storing and providing archival description of the work added to the collection each year.

On the other, the Folklore Archive is beginning, albeit tentatively, to enjoy some recognition from institutions, entities and individuals working on folklore, popular oral literature and intangible heritage in the Balearic Islands.

With a positive outlook to becoming a benchmark institution, the Folklore Archive must face up to three challenges: first, it should be made available to the public (i.e. to researchers and interested users and, therefore, be visible on the internet); second, it should progressively incorporate material from external sources so that the subcollections can grow; and, last but not least, it should become a bibliographic and specialised resource collection. 


\section{References}

BRUNVAND, Jan Harold (200I): "Folklore in the News (and, Incidentally, on the Net)". Western Folklore no. 60:I (winter 200I): 47-66.

Dundes, Alan (I980): “Texture, Text and Context". In Interpreting Folklore. Bloomington: Indiana University Press, p. 20-32.

Dundes, Alan; Carl R. PAGTER (I975): Work Hard and You Shall Be Rewarded: Urban Folklore from the Paperwork Empire. Austin: American Folklore Society.

- (I987): When You're Up to Your Ass in Alligators: More Urban Folklore from the Paperwork Empire. Detroit: Wayne State University Press.

- (I99I): Never Try to Teach a Pig to Sing: Still More Urban Folklore from the Paperwork Empire. Detroit: Wayne State University Press.

- (1995): Sometimes the Dragon Wins: Yet More Urban Folklore from the Paperwork Empire. Syracuse: Syracuse University Press.

- (1999): Why Don't Sheep Shrink When It Rains: A Further Collection of Photocopier Folklore. Syracuse: Syracuse University Press.

GUISCAFRÈ, Jaume (20I4): “Arxivers, filòlegs o folkloristes: per fer què i amb quines eines?". Estudis de Literatura Oral Popular no. 3: 37-48. DOI: http:// dx.doi.org/Io.I7345/elop2OI437-48

ORIOL, Carme (2002): Introducció a l'etnopoètica: Teoria i formes del folklore en la cultura catalana. Valls: Cossetània Edicions.

RoviRó, Ignasi (I992): “Aproximació a l'estudi de la comunicació folklòrica". Ausa no. I28-I29: 7I-IO4.

Toelken, Barre (1996): The Dynamics of Folklore. Logan: Utah State University Press. 